\title{
Analisis Kesesuaian Kualitas air untuk Irigasi pada Beberapa Mataair di Kawasan Karst Sistem Goa Pindul
}

\author{
Agung Hidayat, Slamet Suprayogi dan Ahmad Cahyadi \\ Departemen Geografi Lingkungan, Fakultas Geografi, Universitas Gadjah Mada \\ Yogyakarta
}

\section{Intisari}

Irigasi merupakan faktor yang sangat penting untuk mendukung produktivitas pertanian yang tinggi. Sungai bawah tanah dan mataair di kawasan karst, selain potensial untuk pemenuhan kebutuhan domestic, juga dapat dimanfaatkan untuk kepentingan irigasi lahan pertanian. Penelitian ini bertujuan untuk menganalisis kualitas air dari beberapa mataair yang terdapat di daerah tangkapan Goa Pindul, Kecamatan Karangmjo, Kabupaten Gunungkidul. Data yang dibutuhkan adalah kandungan semua kation dari unsur mayor, meliputi $\mathrm{Ca}^{2+}, \mathrm{Mg}^{2+}, \mathrm{Na}^{+}$dan ditambah dengan ion $\mathrm{K}^{+}$. Kualitas air untuk kelayakan irigasi ditentukan berdasarkan klasifikasi Persentase kandungan Sodium $\left(\mathrm{Na}^{+}\right)$, Sodium Adsorption Ratio, Diagram Wilcox dan Diagram USSL. Hasil analisis menunjukkan bahwa semua sampel dari mataair di daerah tangkapan air Goa Pindul memiliki kualitas yang baik untuk irigasi lahan pertanian.

Kata Kunci: Kebutuhan Air, Kualitas Air, Irigasi, Mataair Karst, Goa Pindul

\section{Pendahuluan}

Proses hidrologi secara sederhana dapat digambarkan dengan adanya hubungan antara masukan berupa air hujan dan keluaran berupa aliran (Hadi, 2006 dalam Setyawan, 2009). Proses hidrologi ini akan menghasilkan suatu ketersedian air yang dapat digunakan untuk berbagai kebutuhan (Cahyadi dkk, 2011). Salah satu kebutuhan yang dapat terpenuhi dengan adanya suatu ketersediaan air adalah kebutuhan air untuk irigasi atau pengairan.

Kebutuhan air untuk irigasi merupakan jumlah volume air yang diperlukan untuk memenuhi kebutuhan evaporasi, kehilangan air, dan kebutuhan air untuk tanaman dengan memperhatikan jumlah ketersediaan air yang diberikan oleh alam melalui air hujan dan lengas tanah. Kebutuhan 
air untuk tanaman ini dapat dipengaruhi oleh beberapa faktor seperti evaporasi, transpirasi dan jenis tanaman.

Kabupaten Gunungkidul sebagai salah satu daerah dengan potensi karst merupakan daerah yang memiliki kendala terkait ketahanan pangan. Masalah kekeringan dan ketersediaan air merupakan faktor penghambat dalam pengembangan pertanian sebagai upaya pemenuhan ketahan pangan (Brontowiyono dkk, 2009; Nurrohmah dkk., 2016). Sebenarnya daerah karst Gunungkidul mempunyai potensi air bawah tanah yang cukup melimpah (Cahyadi dkk., 2013). Hal ini karst merupakan bentuklahan dengan karakteristik hidrologi yang dibentuk oleh kombinasi batuan yang mudah larut dan mempunyai porositas sekunder yang berkembang dengan baik (Cahyadi, 2010; Cahyadi, 2014). Hal ini menyebabkan berkembangnya sungai-sungai bawah tanah dibandingkan sungai permukaan pada kawasan karst (Ford dan Williams, 1992).

Penelitian Mac Donalds dan Partners (1984) di Gunungkidul membuktikan banyak ditemukannya sungai bawah tanah dengan debit yang besar dan melimpah, seperti di Bribin (1500 It/detik), Seropan (1400 It/detik), Baron (800 lt/detik), Ngobaran (150 lt/detik), dan sungai bawah tanah lainnya dengan kurang dari $100 \mathrm{lt} /$ detik. Hal ini menunjukkan bahwa sistem sungai bawah tanah dan mataair di Gunungkidul mempunyai jumlah simpanan yang cukup besar, sehingga potensi ketersediaan air bawah tanah tersebut dapat digunakan untuk mengatasi masalah kekeringan dan pengembangan pertanian melalui irigasi.

Irigasi merupakan upaya penyediaan dan pengaturan air untuk memenuhi kepentingan pertanian dengan memanfaatkan air yang berasal dari permukaan maupun airtanah dan mendistribusinya secara sistematis (Sosrodarsono dan Takeda, 2003). Menurut Peraturan Pemerintah (PP) No. 20 tahun 2006 tentang Irigasi, menyatakan bahwa irigasi merupakan usaha penyediaan, pengaturan dan pembuangan air irigasi untuk menunjang pertanian yang jenisnya meliputi irigasi permukaan, irigasi rawa, irigasi air bawah tanah, irigasi pompa, dan irigasi tambak. Selain untuk memenuhi kebutuhan air tanaman, irigasi atau pengairan ini dimaksudkan untuk mengolah tanah atau lahan guna memperbaiki tata udara tanah, menciptakan kondisi lumpur sebagai tempat tumbuh yang baik bagi tanaman, membantu dalam pembentukan lapisan kedap air, serta sebagai salah satu upaya memberantas gulma (Supriatno, 2003 dalam Akmal dkk, 2014).

Secara umum, sumber air irigasi dapat dibedakan menjadi dua macam, yaitu air permukaan (surface water) dan airtanah (ground water). Air permukaan meliputi air danau alami, air sungai, dan waduk, sedangkan 
airtanah biasanya berasal dari sungai bawah tanah, mataair dan sumur (Nurrohmah dan Cahyadi, 2016). Ketersediaan air permukaan dapat dipengaruhi oleh besarnya curah hujan, sedangkan airtanah dapat dipengaruhi oleh adanya sumur artesis maupun mataair (Schwab dkk, 1981 dalam Kurnia, 2004).

Air yang digunakan sebagai sumber irigasi harus memenuhi syarat atau baku mutu kualitas air tertentu agar tidak membahayakan tanaman dan tidak mempengaruhi hasil tanaman dalam jangka waktu tertentu. Kualitas air irigasi ini dipengaruhi oleh kandungan sedimen dan unsur-unsur kimia yang terkandung di air (Schwab dkk, 1981 dalam Kurnia, 2004). Selain itu, karakter fisik seperti suhu juga memiliki pengaruh yang cukup besar bagi pertumbuhan tanaman.

Sedimen dalam tanah akan berpengaruh terhadap permeabilitas tanah dan menurunkan kesuburan tanah. Apabila sedimen ini terkandung dan mengendap dalam saluran irigasi, maka akan berpengaruh pada kapasitas pengaliran air dan air akan menjadi keruh. Selain kandungan sedimen, unsur kimia juga dapat berpengaruh terhadap kualitas air irigasi. Sifat-sifat kimia dalam air sebagai sumber irigasi pertanian yang penting diketahui meliputi konsentrasi garam terlarut, proporsi garam terhadap kation lain, konsentrasi unsur beracun, konsentrasi bikarbonat, dan kandungan logam berat. Tujuan dari penelitian ini adalah untuk mengetahui kesesuaian sebagian mataair untuk keperluan irigasi di Daerah Tangkapan Sungai Sistem Goa Pindul, Kecamatan Karangmojo, Kabupaten Gunungkidul.

\section{Metode Penelitian}

\subsection{Alat dan Bahan}

Alat dan bahan yang digunakan dalam penelitian ini adalah sebagai berikut:

1. Botol Sampel untuk wadah pengambilan sampel air di lokasi penelitian.

2. Global Positioning System (GPS) untuk mengetahui posisi pengambilan sampel.

3. Software Microsoft Office untuk mengolah dan menganalisis data.

\subsection{Teknik Pengambilan Data}

Pengambilan data untuk penelitian ini terdiri dari dua bagian, yaitu pengambilan sampel air di lapangan dan uji kualitas air di laboratorium. Sampel air di lokasi penelitian diambil dengan menggunakan botol sampel pada setiap titik sampel. Sedangkan uji laboratorium dilakukan untuk 
mengetahui seberapa besar kandungan parameter unsur mayor dalam sampel air. Parameter yang digunakan yaitu sodium $\left(\mathrm{Na}^{+}\right)$, kalsium $\left(\mathrm{Ca}^{+}\right)$, magnesium $\left(\mathrm{Mg}^{2+}\right)$, dan potasium $\left(\mathrm{K}^{+}\right)$.

\subsection{Teknik Analisis Data}

Analisis data dilakukan dengan melihat beberapa parameter unsur mayor yang terkandung dalam sampel air dan besarnya Daya Hantar Listrik (DHL). Teknik analisis data dalam penelitian ini yaitu sebagai berikut:

\subsubsection{Analisis Sodium}

Perhitungan sodium ( $\mathrm{Na} \%$ ) digunakan untuk mengetahui reaksi terhadap kondisi tanah dan pengaruhnya terhadap permeabilitas. Konsentrasi sodium dapat ditentukan dengan persamaan 1.

$$
N a \%=\frac{(N a+K) 100}{(C a+M g+N a+K)}
$$

Keterangan: konsentrasi ion dalam miliequivalent per liter

Konsentrasi sodium yang diperoleh selanjutnya dapat diklasifikasikan sesuai dengan klasifikasi kesesuaian air untuk keperluan irigasi menurut Wilcox (1948) dalam Suhana dan Cahyadi (2015) (Tabel 1).

Tabel 1. Klasifikasi Konsentrasi Sodium untuk Kesesuaian Irigasi

\begin{tabular}{|c|c|c|}
\hline Klasifikasi & Konsentrasi Sodium (Na\%) & Kelas Air \\
\hline S1 & $<20$ & Excellent \\
\hline S2 & $20-40$ & Good \\
\hline S3 & $40-60$ & Permissible \\
\hline S4 & $60-80$ & Doubtful \\
\hline S5 & $>80$ & Unsuitable \\
\hline
\end{tabular}

Sumber: Wilcox (1948) dalam Suhana dan Cahyadi (2015)

\subsubsection{Analisis Sodium Adsorption Ratio}

Sodium Adsorption Ratio digunakan untuk menunjukkan adanya hubungan langsung antara sodium adsorption terhadap tanah. Analisis dengan Sodium Adsorption Ratio melihat hubungan antara nilai perbandingan serapan sodium dan nilai konduktivitas air sehingga dapat diketahui kualitas air untuk keperluan irigasi atau pertanian. Nilai SAR dapat ditentukan dengan persamaan 2. 
$\mathrm{SAR}=\frac{\mathrm{Na}}{\sqrt{(\mathrm{Ca}+\mathrm{Mg}) / 2}}$

Keterangan: konsentrasi ion dalam miliequivalent per liter

Nilai SAR yang diperoleh selanjutnya dapat diklasifikasikan sesuai dengan klasifikasi kesesuaian air untuk keperluan irigasi menurut USSL (1954) dalam Sadashivaiah (2008) (Tabel 2).

Tabel 2. Klasifikasi SAR untuk Kesesuaian Irigasi

\begin{tabular}{|c|l|c|}
\hline Klasifikasi & \multicolumn{1}{|c|}{ SAR } & Kelas Air \\
\hline S1 & $<10$ & Excellent \\
\hline S2 & $10-18$ & Good \\
\hline S3 & $18-26$ & Doubtful \\
\hline S4 & $>26$ & Unsuitable \\
\hline
\end{tabular}

Sumber: (USSL, 1954 dalam Sadashivaiah, 2008)

\subsubsection{Analisis dengan Diagram Wilcox}

Diagram wilcox digunakan untuk melihat perbandingan persentase sodium dengan daya hantar listrik, serta menunjukkan hubungan antara kecenderungan tingkat daya hantar listrik terhadap besaran konsentrasi sodium pada air. Diagram Wilcox sebenarnya merupakan gabungan antara parameter Daya Hantar Listrik dengan Persentase Sodium. Berdasarkan digaram Wilcox ini akan terlihat tingkat keseuaian air untuk irigasi dengan kondisi paling sesuai adalah sampel dengan nilai $\mathrm{DHL}$ dan konsentrasi sodium yang rendah, sedangkan kondisi paling tidak sesuai adalah sampel dengan nilai $\mathrm{DHL}$ dan konsentrasi sodium yang tinggi.

\subsubsection{Analisis dengan Diagram USSL}

Diagram USSL digunakan untuk mengetahui hubungan dan pengaruh yang dapat terjadi antara salinity hazard dengan sodium hazard. Diagram USSL sebenarnya hampir sama dengan diagram wilcox, namun pada diagram USSL parameter yang digunakan adalah nilai Daya Hantar Listrik dan Sodium Adsorption Ratio. SAR digunakan karena berkaitan secara langsung terhadap penyerapan Natrium oleh tanah (Todd, 1980). Berdasarkan Diagram USSL ini akan ditentukan konsentrasi total garam terlarut berdasarkan pola besaran daya hantar listrik. Hubungan antara tingkat salinitas air dan tingkat kelas sodium tersebut akan menghasilkan tingkat kesesuaian air untuk keperluan irigasi. 


\section{Hasil dan Pembahasan}

Hasil pengujian beberapa parameter unsur mayor terhadap 5 titik lokasi penelitian menunjukkan variasi nilai yang tergolong masih memenuhi standar bakumutu air untuk keperluan irigasi (Tabel 3). Untuk parameter sodium $(\mathrm{Na}+)$ dan potasium $\left(\mathrm{K}^{+}\right)$kelima sampel air memiliki nilai yang tidak jauh berbeda, yaitu parameter sodium $(\mathrm{Na}+)$ berkisar antara $0,83 \mathrm{meq} / \mathrm{l}$ hingga $1,13 \mathrm{meq} / \mathrm{l}$ dan parameter potasium $\left(\mathrm{K}^{+}\right)$berkisar antara $0,03 \mathrm{meq} / \mathrm{l}$ hingga $0,08 \mathrm{meq} / \mathrm{l}$. Sedangkan untuk parameter magnesium $\left(\mathrm{Mg}^{2+}\right)$ dan kalsium $(\mathrm{Ca}+)$, untuk sampel di mataair Gunung Abang menunjukkan nilai yang cukup berbeda. Kandungan kalsium di mataair Gunung Abang sebesar 2,3 meq/l sedangkan mataair lainnya memiliki kandungan kalsium sebesar 4,75-5,7 meq/l. Sama seperti kandungan kalsiumnya, untuk kandungan magnesium di mataair Gunung Abang sebesar 4,29 meq/l sedangkan mataair lainnya memiliki kandungan magnesium sebesar 0,48$0,88 \mathrm{meq} / \mathrm{l}$.

Tinggi rendahnya kandungan magnesium dan kalsium sebenarnya juga dapat dilihat dari seberapa besar kesadahan air, namun terkadang salah satu dari ion logam tersebut akan cenderung lebih dominan dibandingkan dengan ion logam lainnya. Kandungan kalsium lebih dipengaruhi oleh adanya reaksi yang melibatkan gas $\mathrm{CO}_{2}$, baik itu karena respirasi tumbuhan maupun hewan aquatik. Sedangkan kandungan magnesium lebih dipengaruhi oleh magnesium sulfat dan magnesium klorida yang mudah larut, sehingga air yang mengalami kontak dengan kedua senyawa tersebut akan memiliki kandungan magnesium yang tinggi. Sehingga tingginya kandungan magnesium di mataair Gunung Abang dapat diindikasikan karena banyaknya magnesium sulfat dan magnesium klorida yang mengalami kontak dengan mataair tersebut dan larut didalamnya.

Daya Hantar Listrik merupakan salah satu parameter yang diukur langsung di lokasi penelitian. DHL ini berguna untuk mengetahui kandungan salinitas atau konsentrasi garam-garaman dalam air. Besarnya konsentrasi garam-garaman dalam air dapat dilihat dari seberapa besar nilai Daya Hantar Listriknya. Semakin tinggi nilai DHL maka kandungan salinitas dalam air tersebut juga akan semakin tinggi. Nilai DHL dari kelima sampel mataair tergolong sedang, yaitu berkisar antara 500-700 $\mu \mathrm{mhos} / \mathrm{cm}$. 
Tabel 3. Hasil Pengukuran Parameter Keseuaian Air untuk Keperluan Irigasi

\begin{tabular}{|l|r|r|r|r|r|}
\hline \multicolumn{1}{|c|}{ Mataair } & $\begin{array}{c}\mathbf{N a} \\
(\mathbf{m g} / \mathbf{l})\end{array}$ & $\begin{array}{c}\mathrm{K} \\
(\mathbf{m g} / \mathbf{l})\end{array}$ & $\begin{array}{c}\mathbf{C a} \\
(\mathbf{m g} / \mathbf{l})\end{array}$ & $\begin{array}{c}\text { Mg } \\
(\mathbf{m g} / \mathbf{l})\end{array}$ & $\begin{array}{c}\text { DHL } \\
(\boldsymbol{\mu m h o s} / \mathbf{c m})\end{array}$ \\
\hline Outlet Pindul & 0,83 & 0,03 & 5,15 & 0,52 & 627 \\
\hline Mudal & 1,00 & 0,05 & 5,70 & 0,48 & 629 \\
\hline Suruh & 0,87 & 0,03 & 4,75 & 0,64 & 684 \\
\hline Ngancar & 0,83 & 0,03 & 5,27 & 0,88 & 585 \\
\hline Gunung Abang & 1,13 & 0,08 & 2,30 & 4,29 & 670 \\
\hline
\end{tabular}

Sumber: Hasil analisis Laboratorium

Pengukuran konsentrasi sodium menunjukkan hasil yang tidak jauh berbeda untuk kelima sampel mataair. Nilai konsentrasi sodium berkisar antara $13 \%$ hingga $15,5 \%$, sehingga berdasarkan nilai konsentrasi sodiumnya, mataair di Outlet Pindul, Mudal, Suruh, Ngancar, dan Gunung Abang tergolong dalam klasifikasi sangat baik apabila digunakan untuk keperluan irigasi (tabel 4). Rendahnya kandungan sodium dalam air tentu berdampak baik untuk tanaman pertanian karena kandungan sodium yang rendah tidak akan mengganggu pertumbuhan tanaman.

Tabel 4 Hasil Pengukuran Konsentrasi Sodium

\begin{tabular}{|l|r|l|}
\hline \multicolumn{1}{|c|}{ Mataair } & \multicolumn{1}{|c|}{$\begin{array}{c}\text { Konsentrasi Sodium } \\
\text { (Na\%) }\end{array}$} & Kelas Air \\
\hline Outlet Pindul & 13,06 & Excellent \\
\hline Mudal & 14,53 & Excellent \\
\hline Suruh & 14,23 & Excellent \\
\hline Ngancar & 12,17 & Excellent \\
\hline Gunung Abang & 15,49 & Excellent \\
\hline
\end{tabular}

Sumber: Hasil analisis data

Pengukuran Sodium Adsorption Ratio untuk kelima sampel mataair juga menunjukkan hasil yang tidak jauh berbeda, yaitu nilai SAR berkisar antara 0,47 hingga 0,62 (Tabel 5). Nilai tersebut tergolong rendah, sehingga berdasarkan Sodium Adsorption Ratio kelima mataair, yaitu mataair di Outlet Pindul, Mudal, Suruh, Ngancar, dan Gunung Abang tergolong dalam klasifikasi sangat baik dan sangat sesuai apabila digunakan untuk pengairan pertanian atau irigasi. Rendahnnya nilai SAR berpengaruh pada rendahnya adsorpsi sodium oleh tanah, sehingga struktur tanah tetap dapat terjaga dan tanaman dapat tumbuh secara optimal. 
Tabel 5. Hasil Pengukuran Sodium Adsorption Ratio

\begin{tabular}{|l|r|l|}
\hline \multicolumn{1}{|c|}{ Mataair } & \multicolumn{1}{c|}{ SAR } & Kelas Air \\
\hline Outlet Pindul & 0,49 & Excellent \\
\hline Mudal & 0,57 & Excellent \\
\hline Suruh & 0,53 & Excellent \\
\hline Ngancar & 0,47 & Excellent \\
\hline Gunung Abang & 0,62 & Excellent \\
\hline
\end{tabular}

Sumber: Hasil analisis data

Klasifikasi Kesesuaian Air Irigasi pada kelima sampel mataair menurut diagram Wilcox menunjukkan bahwa seluruh sampel tergolong dalam klasifikasi excellent to good (gambar 1). Kondisi ini dapat dilihat dari nilai DHL pada kelima sampel yang tidak terlalu tinggi. Berdasarkan klasifikasi diagram wilcox dapat diindikasikan bahwa mataair di Outlet Pindul, Mudal, Suruh, Ngancar, dan Gunung Abang memiliki kandungan sodium yang tidak terlalu tinggi dan salinitas yang rendah karena seluruh sampel mataair memiliki DHL dibawah 750 micromhos $/ \mathrm{cm}$. Dengan demikian seluruh sampel mataair tersebut sesuai untuk digunakan sebagai air irigasi.

Klasifikasi Kesesuaian Air Irigasi menurut diagram USSL menunjukkan hasil yang tidak jauh berbeda seperti diagram Wilcox. Berdasarkan klasifikasi diagram USSL, kelima sampel mataair tergolong dalam kelas C2S1 atau memiliki kesesuaian sedang hingga baik untuk keperluan irigasi. Klasifikasi menurut diagram USSL ini menunjukkan bahwa kelima sampel mataair memiliki risiko salinitas menengah risiko sodium yang rendah, sehingga sesuai apabila digunakan untuk keperluan irigasi. Klasifikasi menurut diagram USSL ini dapat membantu untuk rekomendasi jenis tanaman yang akan ditanam karena dapat memberikan informasi mengenai seberapa besar toleransi kandungan sodium dan salinitas dalam air. 


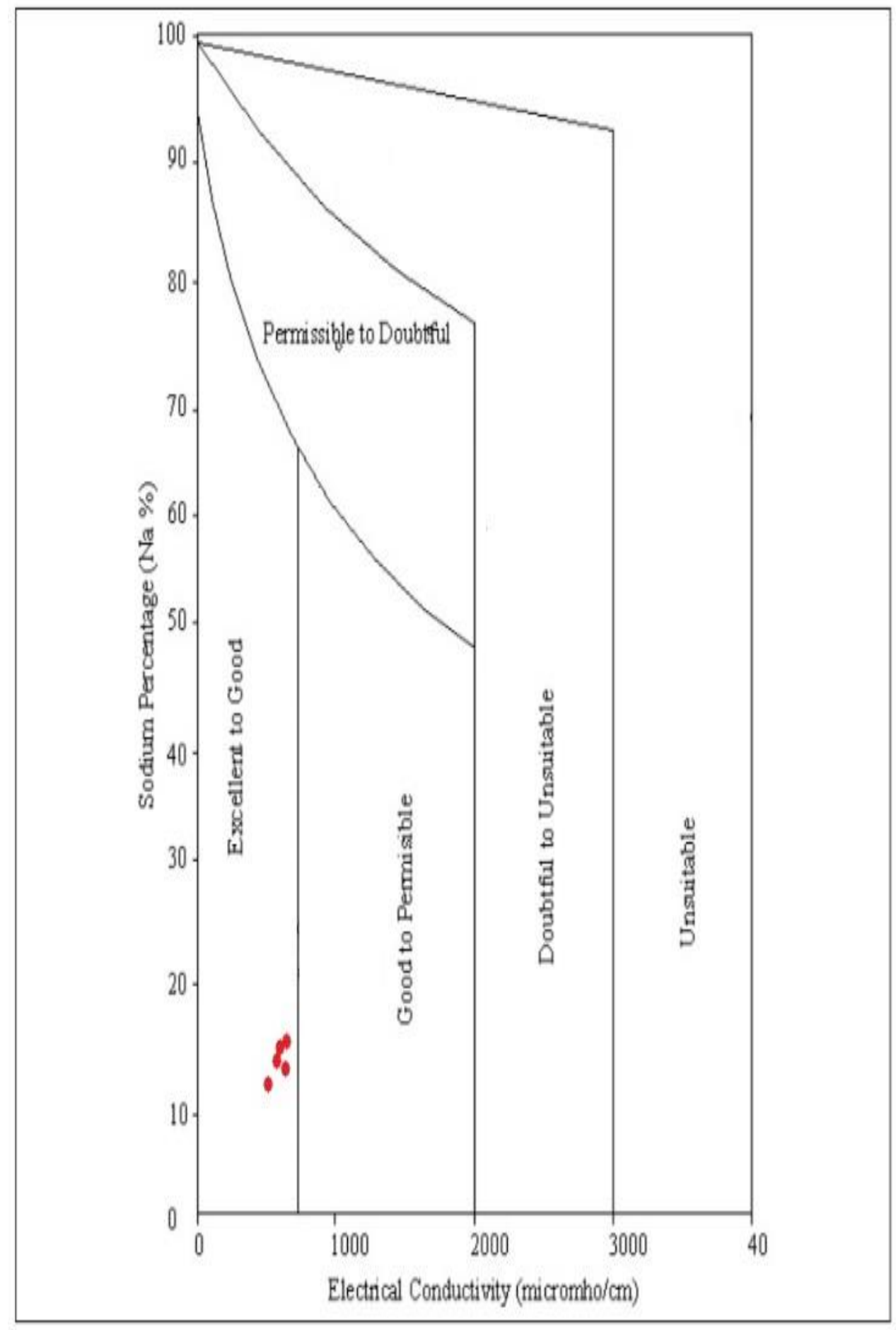

Gambar 1. Diagram Klasifikasi Kesesuaian Air Irigasi Wilcox (Diagram diperoleh dari Sadashivaiah, 2008) 


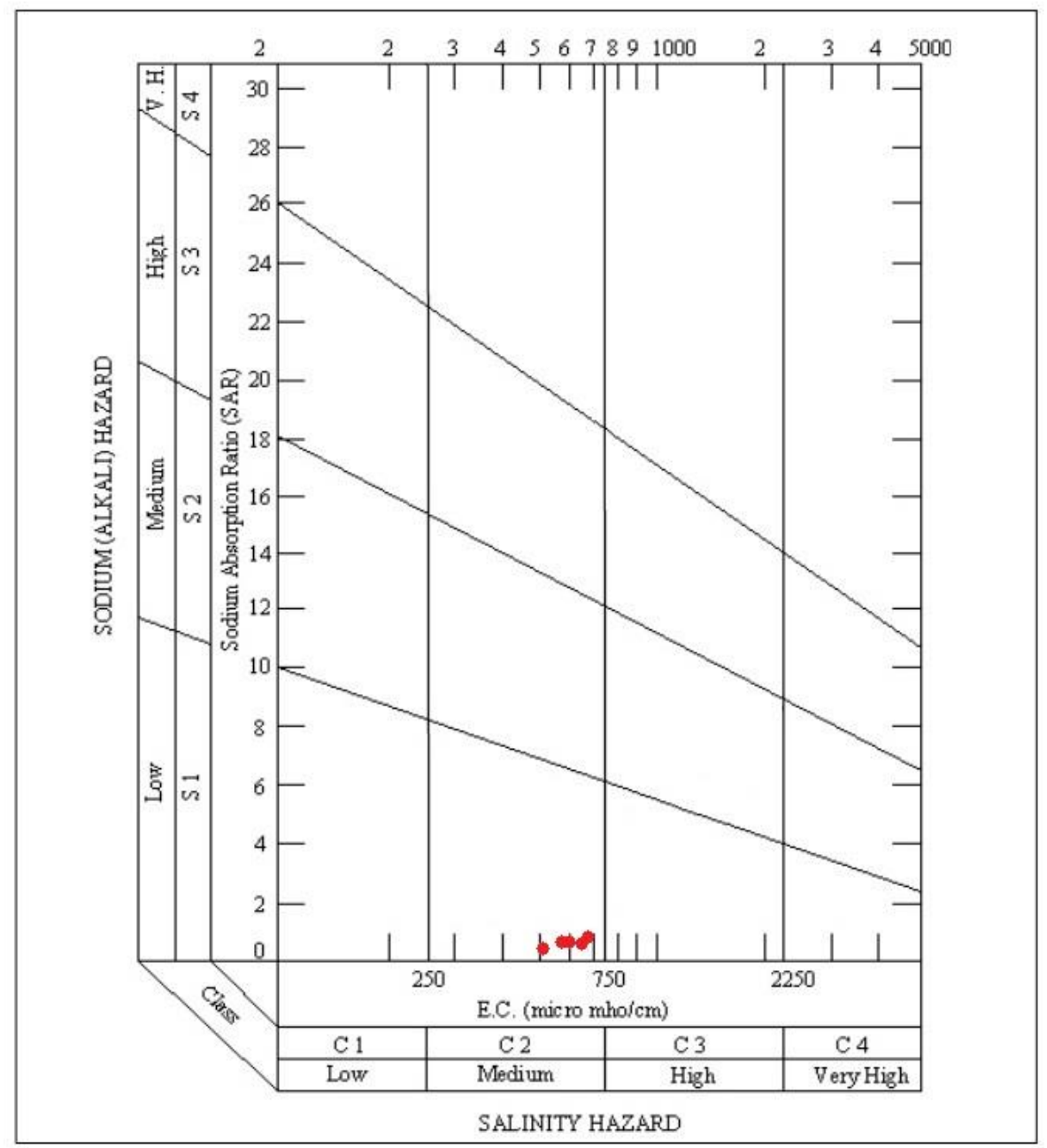

Gambar 2. Diagram Klasifikasi Kesesuaian Air Irigasi USSL (Diagram diperoleh dari Sadashivaiah, 2008)

Berdasarkan penggabungan dari 4 klasifikasi sebelumnya, yaitu $\mathrm{Na} \%$, SAR, diagram Wilcox, dan diagram USSL dapat dikelompokkan menjadi kualitas baik, sedang, dan buruk. Hasil analisis terhadap kelima sampel mataair di Kawasan Karst Sistem Goa Pindul dengan 4 metode yang berbeda didapati bahwa mataair di Outlet Pindul, Mudal, Suruh, Ngancar, dan Gunung Abang dapat digunakan untuk keperluan irigasi. Dengan demikian, seluruh mataair tersebut memiliki kualitas baik untuk pengairan pertanian atau irigasi dan tidak memberikan dampak negatif bagi tanaman pertanian, karena seluruh parameter unsur kimia masih berada dalam ambang batas bakumutu air. 


\section{Penutup}

\subsection{Kesimpulan}

Hasil analisis terhadap kelima sampel mataair di Kawasan Karst Sistem Goa Pindul, yaitu di Outlet Goa Pindul, Mudal, Suruh, Ngancar, dan Gunung Abang dapat diambil kesimpulan bahwa seluruh mataair tersebut memiliki kualitas baik dan sesuai digunakan untuk keperluan irigasi. Pengetahuan tentang kualitas air irigasi tersebut selanjutnya dapat digunakan sebagai acuan dalam perencanaan budidaya tanaman pertanian, sehingga diperoleh hasil yang maksimal.

\subsection{Saran}

Hasil penelitian mengenai kualitas air di Kawasan Karst Sistem Goa Pindul menunjukkan seluruh mataair di kawasan ini memiliki kualitas baik untuk keperluan irigasi. Namun untuk memperkuat bahwa mataair di Kawasan Karst Sistem Goa Pindul ini sesuai digunakan untuk irigasi diperlukan penelitian terkait yang lebih lanjut, seperti penelitian mengenai debit aliran maupun ketersediaan air untuk mengetahui pemenuhan kebutuhan air pertanian serta pengujian terhadap unsur-unsur kimia lain agar kualitas airnya dapat dikaji secara lebih lengkap.

\section{Pengakuan}

Penelitian ini merupakan bagian dari hibah Penelitian Unggulan Perguruan Tinggi (PUPT) Kementerian Riset, Teknologi dan Pendidikan Tinggi (Kemenristekdikti) tahun 2016 yang berjudul "Karakterisasi Hidrologi dan Banjir di Sungai Bawah Tanah Goa Pindul untuk Pengelolaan Pariwisata Berkelanjutan Berbasis Manajemen Kebencanaan" dengan nomor kontrak 679/UN1-P.III/LT/DIT-LIT/2016.

\section{Daftar Pustaka}

Akmal; Masimin dan Mellianda; E. 2014. Efisiensi Irigasi Pada Petak Tersier di Daerah Irigasi Lawe Bulan Kabupaten Aceh Tenggara. Jurnal Teknik Sipil Pascasarjana Universitas Syiah Kuala, 3(3): 20-37.

Brontowiyono, W.; Lupiyanto, R and Malik, A.H. 2009. Improving Carrying Capacity by Developing Rainwater Harvesting: A Case of Oyo Watershed. Jurnal Sains dan Teknologi Lingkungan Universitas Islam Indonesia, 1(1): 86-98.

Cahyadi, A. 2010. Pengelolaan Kawasan Karst dan Peranannya dalam Siklus Karbon di Indonesia. Prosiding Seminar Nasional Perubahan Iklim. Yogyakarta: Sekolah Pascasarjana Universitas Gadjah Mada. 
Cahyadi, A. Priadmodjo, A. and Yananto, A. 2011. Criticizing The Conventional Paradigm of Urban Drainage. Proceeding The 3rd International Graduated Student Conference on Indonesia. Yogyakarta: Graduate School, Universitas Gadjah Mada.

Cahyadi, A.; Pratiwi. E.S. dan Fatchurohman, H. 2013. Metode-metode Identifikasi Karakteristik Daerah Tangkapan Air Sungai Bawah Tanah dan Mata Air Kawasan Karst: Suatu Tinjauan. dalam Marfai, M.A. dan Widyastuti, M. 2013. Pengelolaan Lingkungan Zamrud Khatulistiwa. Yogyakarta: Pintal. Hal: 50 -61.

Cahyadi, A. 2014. Keunikan Hidrologi Kawasan Karst: Suatu Tinjauan. dalam Cahyadi, A.; Prabawa, B.A.; Tivianton, T.A. dan Nugraha, H. 2014. Ekologi Lingkungan Kawasan Karst Indonesia: Mejaga Asa Kelestarian Kawasan Karst Indonesia, Edisi 2. Yogyakarta: Deepublish. Hal: 1 - 13.

Ford, D.C. dan Williams P.W. 1992. Karst Geomorphology and Hydrogeology. London: Champman and Hall.

Nurrohmah, H.; Sudarmadji dan Cahyadi, A. 2016. Kajian Kekeringan Meteorologis dan Kaitannya dengan Agihan Mata Air di Kabupaten Kulonprogo, Daerah Istimewa Yogyakarta. Prosiding Seminar Nasional Geografi Lingkungan I. Yogyakarta: Badan Penerbit Fakultas Geografi Universitas Gadjah Mada.

Nurrohmah, H. dan Cahyadi, A. 2016. Analisis Pemenuhan Kebutuhan Air Domestik dengan Airtanah di Daerah Aliran Sungai Kayangan Kabupaten Kulonprogo. Prosiding Seminar Nasional II Pengelolaan Pesisir dan Daerah Aliran Sungai. Yogyakarta: Magister Pengelolaan Pesisir dan Daerah Aliran Sungai, Fakultas Geografi Universitas Gadjah Mada.

Kurnia, U. 2004. Prospek Pengairan Pertanian Tanaman Semusim Lahan Kering. Jurnal Litbang Pertanian, 4(23): 130-138.

Mac Donald dan Partners. 1984. Greater Yogyakarta Groundwater Resources Study Vol. $3^{\text {rd }}$ Groundwater Goverment of The Republic Indonesia, Ministry of Public Works, Directorate General of Water Resources Development. Groundwater Development Project.

Mukherjee, S.; Abhimanyu, B.K. dan Kortvelyessy, L. 2005. Assessment of Groundwater Quality In The South 24-Parganas, West Bengal Coast, India. Journal of Environmental Hydrology, 13(15): 1-8.

Peraturan Pemerintah Republik Indonesia Nomor 20 Tahun 2006 Tentang Irigasi. 
Sadashivaiah, C.; Ramakrishnaiah, R. dan Ranganna, G. 2008. Hydrochemical Analysis and Evaluation of Groundwater Quality in Tumkur Taluk, Karnataka State, India. International Journal Res. Public Health, 5(3): 158-164.

Setyawan, P. 2009. Neraca Air di Pulau Bali. Forum Geografi, 23(1): 57-70. Sosrodarsono, S. dan Takeda, K. 2003. Hidrologi untuk Pengairan. Jakarta: Pradna Paramita.

Suhana, S.N. dan Cahyadi, A. 2015. Penaksiran Kesesuaian Kualitas Airtanah untuk Irigasi di Sebagian Mataair Kabupaten Rembang. Prosiding Seminar Nasional Innovation in Environmental Management 2015. Semarang: Universitas Diponegoro dan Queensland University.

Todd, D.K. 1980. Ground Water Hydrology. New York: John Willey and Sons Inc.

Makalah ini merupakan bagian dari Buku Seri Bunga Rampai dengan Judul "Hidrologi dan Kepariwisataan Kawasan karst Goa Pindul Kabupaten Gunungkidul" dengan Editor Slamet Suprayogi, Setyawan Purnama, Ahmad Cahyadi, Hendy Fatchurohman. Buku ini diterbitkan oleh Badan Penerbit Fakultas Geografi (BPFG) Universitas Gadjah Mada di Yogyakarta Tahun 2016. Makalah ini termuat dalam Halaman 42-55 